\title{
On Luigi Nono's Political Thought: Emancipation Struggles, Socialist Hegemony and the Ethic Behind the Composition of Für Paul Dessau
}

\author{
LUIS VELASCO-PUFLEAU
}

\begin{abstract}
The musical activism of the Italian composer Luigi Nono (1924-1990) is one of the most fascinating examples of the relationship between music and politics in the second half of the twentieth century. A member of the Italian Communist Party (PCI) from 1952, he considered music as a tool for the establishment of socialist hegemony. In this article, I first examine how concepts from Antonio Gramsci underlie Nono's political thought, the relationship between his conception of social justice struggles and violence, and the ethic behind his compositional practice. Secondly, I analyze how Nono addressed his political and ethical commitment in his last work for magnetic tape, Für Paul Dessau (1974). This article aims to contribute to the discussion on Nono's appropriation of Gramsci's ideas, shedding light on how Nono addressed the memory of antifascism, Cold War politics, and Third World international liberation struggles in works from the 1950s to the early 1970s.
\end{abstract}

\section{Introduction}

In 1971 the Italian composer Luigi Nono (1924-1990) described himself as an "activist-musician not above but within the class struggle as it exists." ${ }^{1}$ This idea refers to one of Nono's biggest concerns: how to reconcile in a coherent manner his artistic activity as a composer with his political commitment and the role he granted himself in the transformation of society. As Nono asserted in 1969, for him there was "no difference between music and politics", since through music composition he aimed to contribute "to class struggle and help to push it forward."

Nono saw himself as an Antonio Gramsci "organic intellectual belonging to the working class" and considered Gramsci as a model for his own political thought. ${ }^{4}$ In fact, Nono's political activism was rooted

\footnotetext{
1 "Musicien militant non au-dessus mais dans la lutte des classes telle qu'elle existe," Le Monde, 16 May 1971, published as Luigi Nono, "Une lettre de Luigi Nono : 'Je suis un musicien militant," in Luigi Nono: Écrits, ed. and trans. Laurent Feneyrou (Genève: Éditions Contrechamps, 2007), 347. Italian version: Luigi Nono, "Una lettera di Luigi Nono: 'Sono un musicista militante' (1971)," in Luigi Nono: Scritti e colloqui, ed. Angela Ida De Benedictis and Veniero Rizzardi, vol. I (Milan and Lucca: Ricordi and LIM, 2001), 288. Translations from French, Italian, and Spanish are by the author, except English translations from Luigi Nono's “Musica e Resistenza," (1963) and "Il potere musicale" (1969)—these translations will be published in Angela Ida De Benedictis and Veniero Rizzardi (eds.), Nostalgia for the Future. Luigi Nono's Selected Writings and Interviews (Oakland: University of California Press, 2018). I would like to thank Angela Ida De Benedictis and Veniero Rizzardi for kindly sharing with me the translated quotes from these texts.

2 "Per me non c'è più differenza tra musica o politica. Componendo musica contribuisco alla lotta di classe e la aiuto a spingersi avanti," Luigi Nono, "Intervista di Hansjörg Pauli," in Luigi Nono: Scritti e colloqui, ed. Angela Ida De Benedictis and Veniero Rizzardi, vol. II (Milan and Lucca: Ricordi and LIM, 2001), 31.

3 "Intellectuel faisant partie de la classe ouvrière," Nono, "Une lettre de Luigi Nono : 'Je suis un musicien militant," 347.

${ }^{4}$ The Italian intellectual Antonio Gramsci (1891-1937) was a founding member of the Italian Communist Party (PCI). He
} 
in a particular combination of Italian Marxism, postwar antifascism, and Third World anti-imperialism. This combination reveals the significance that the emancipation struggles in Latin America, Asia, and Africa had for him.

Nono was a member of the Italian Communist Party (PCI) from 1952. In the late 1960s and early 1970s he sought the development of a socialism that respects the diversity of political, economic, and cultural aspects of different peoples. In a letter he wrote in 1971 to the editor-in-chief of $L^{\prime}$ Unità, ${ }^{5}$ he advocated the realization of a socialism "inspired by Lenin, Gramsci, and Sovietism, in the wake of the liberation struggles in Asia [...], in Africa and in Latin America." Nono linked this interpretation of socialism with the international workers struggles and civil rights movements of that time: "the socialism for which the workers of the Baltic region are struggling, as well as those from Detroit and the Black Panthers in the stronghold of imperialism."7

When I published in 2014 a first version of this essay in French, ${ }^{8}$ the relationship between the work of Gramsci and the formation of Nono's political thought had been discussed very little in Englishlanguage Nono scholarship. One of the reasons for this is that his writings and interviews had not been translated into English. ${ }^{9}$ However, in an essay published in 2016, Robert Adlington discusses in depth Nono's interpretation of Gramsci as well as his ideological relationship with other leftist political and cultural movements in Italy during the 1960s and 1970s, such as workerists and folklorists. ${ }^{10}$ Adlington points out some of the tensions of Nono's Marxist and artistic activism; for instance, the fact that Nono considered himself as an "organic intellectual" - in Gramscian terms—while "he could not plausibly claim to be working class himself." 11 In a thorough analysis of Gramsci's thought, Adlington asserts that the reading of Gramsci was never neutral in Italy, and that his writings were "politically instrumentalized after the war by all sides."12 Furthermore, he affirms that "Nono advanced a reading of Gramsci that was in fact highly idiosyncratic, resulting in a stance that in significant respects misrepresented his compatriot's arguments." ${ }^{\prime 3}$ Through the analysis of Nono's Voci destroying muros, Adlington argues that this "work forms a new response to the debates around subaltern representation, one susceptible to analysis from both workerist and (authentically) Gramscian perspectives." ${ }^{14}$

\footnotetext{
died in one of Benito Mussolini's prisons where he wrote most of his work.

${ }^{5}$ Italian left-wing newspaper founded by Gramsci in 1924. It was the official newspaper of the Italian Communist Party until its dissolution in 1991.

6 "Che abbiamo imparato da Lenin da Gramsci dal soviettismo dalle conduzioni delle lotte di liberazione in Asia [...], in Africa e in parte dell'America latina," Luigi Nono, "Luigi Nono a 'L'Unità' [Venezia, gennaio 1971]," in Luigi Nono: carteggi concernenti politica, cultura e Partito comunista italiano, ed. Antonio Trudu (Venezia: L.S. Olschki and Archivio Luigi Nono, 2008), 178.

7 "Quel socialismo per cui lottano gli operai della regione baltica, fino a quelli di Detroit e al movimento dei Black Panthers nella roccaforte dell'imperialismo," Nono, 178.

${ }^{8}$ This article is a significantly revised version of a previous text published in French as Luis Velasco-Pufleau, "Conflits armés, idéologie et technologie dans Für Paul Dessau de Luigi Nono,” Transposition. Musique et sciences sociales, no. 4 (2014), https://doi.org/10.4000/transposition.1060. I am grateful to Music E Politics anonymous reviewers and editors for their valuable and helpful comments.

${ }^{9}$ The two-volume Italian edition of his writings and interviews was published in 2001. The University of California Press will publish in 2018 a translation of Nono's selected writings and interviews (see note 1).

${ }^{10}$ Robert Adlington, “Whose Voices? The Fate of Luigi Nono's Voci Destroying Muros,” Fournal of the American Musicological Society 69, no. 1 (2016): 179-236, https://doi.org/10.1525/jams.2016.69.1.179.

${ }^{11}$ Adlington, 191.

${ }^{12}$ Paolo Capuzzo and Sandro Mezzadra, "Provincializing the Italian Reading of Gramsci," in The Postcolonial Gramsci, ed. Neelam Srivastava and Baidik Bhattacharya (New York and London: Routledge, 2012), 35. Quoted in Adlington, "Whose Voices?," 189.

${ }^{13}$ Adlington, "Whose Voices?," 181.

${ }^{14}$ Adlington, 182.
} 
This article aims to contribute to the understanding of Nono's political thought as this is articulated alongside his aesthetic ideas and compositional technique in the first half of the 1970s. Rather than developing an analysis of Nono's interpretation of Gramsci in terms of "authenticity," I examine the tensions and contradictions of his political thought within his aspiration to advance the international class struggle for social justice through his musical production. I then analyze how Nono tried to overcome these tensions with the use of technology and historical recorded archives in his last work for magnetic tape Für Paul Dessau (1974). ${ }^{15}$ In doing so, this article contributes to the discussion on Nono's appropriation of Gramsci's ideas, shedding light on how Nono addressed the memory of antifascism, Cold War politics, and Third World international liberation struggles in works from the 1950s to the early 1970s.

I first refer to Nono's interpretation of three concepts from Antonio Gramsci: ideology, hegemony, and the organic intellectual. By drawing on Nono's writings and interviews, I examine how these concepts underlie his political thought, the relationship between his conception of social justice struggles and violence, and the ethic behind his musical activism and compositional practice. Nono's appropriation of Gramsci's concepts depended on both the postwar debates on Gramsci, which were dominated in Italy by the PCI interpretation, ${ }^{16}$ and the international reception of Gramsci's writings after 1950. As Geoff Eley characteristically noted in 1982, in the English speaking academic world, "every one, it seems, has their own Gramsci, and the present author is certainly no exception." 17 This is partly due to the complex, fragmentary, and sometimes ambiguous character of Gramsci's texts, in particular his Prison Notebooks. In any case, a reading of Gramsci has never been neutral; his work continues to be discussed intensely in social sciences, leading at times to strong divergences between scholars' viewpoints. ${ }^{18}$

Secondly, I analyze how Nono addressed his political and ethical commitment in Für Paul Dessau, a seven-minute piece composed in 1974 at the Studio di Fonologia of the Milano RAI (with the technical assistance of Marino Zuccheri). It was dedicated to his friend, the German composer Paul Dessau (18941979), for his eightieth birthday. Nono performed this work in a tribute-concert for Dessau on December 15, 1974 at the Academy of Arts in East Berlin. ${ }^{19}$ Despite the fact that Für Paul Dessau has received very little attention in Nono scholarship, this work can be examined as the synthesis of the compositional processes, the use of new technologies, and the political themes he developed during the preceding years. ${ }^{20}$ It was both the last of his work for magnetic tape and the last of a long line of works with explicit political

\footnotetext{
${ }^{15}$ A recording of Für Paul Dessau is available on Youtube: https://youtu.be/CnGwMPLKYjU. Nono's catalogue of works for solo magnetic tape: Omaggio a Emilio Vedova (1960), Musiche di scena per Die Ermittlung (1965), Ricorda cosa ti hanno fatto in Auschwitz (1966), Contrappunto dialettico alla mente (1967-1968), Musiche per Manzù (1969) et Für Paul Dessau (1974), see Luigi Nono, Complete Works for Solo Tape, 2 CDs and booklet (Milan: Stradivarius Ricordi Oggi, 2006).

${ }^{16}$ See Adlington, "Whose Voices?," 188-94.

${ }^{17}$ Geoff Eley, "Reading Gramsci in English: Observations on the Reception of Antonio Gramsci in the English-Speaking World 1957-82," in Antonio Gramsci, ed. James Martin, vol. 4: Contemporary Applications (London: Routledge, 2002 ), 28.

${ }^{18}$ For example, on Gramsci's conception of the connection between democracy and hegemony, see Dylan J. Riley,

"Hegemony, Democracy, and Passive Revolution in Gramsci's Prison Notebooks," California Italian Studies 2, no. 2 (2011), https://escholarship.org/uc/item/5x48f0mz.

${ }^{19}$ Nono traveled on a regular basis to East Germany for performances of his music and of his works by his friend Paul Dessau. As Carola Nielinger-Vakil asserts, "Nono actively sought contact with intellectuals of the Socialist East in order to work against an all too dogmatic and bureaucratic form of socialism." This assertion can also be applied to Latin America. See Carola Nielinger-Vakil, Luigi Nono: A Composer in Context (Cambridge: Cambridge University Press, 2015$), 20$.

${ }^{20}$ Für Paul Dessau was connected to several other of Nono's older pieces by the material, texts, and political subjects to which it referred, in particular: Il canto sospeso (1955-1956), La fabbrica illuminata (1964), A floresta é jovem e cheja de vida (1966), Non consumiamo Marx (1969), Y entonces comprendió (1970), Ein Gespenst geht um in der Welt (1971), Como una ola de fuerza y luz (1971-1972) and Al gran sole carico d'amore (1972-1974). For a complete overview of the catalogue of Luigi Nono, see Laurent Feneyrou, ed., Luigi Nono: Écrits, trans. Laurent Feneyrou (Genève: Éditions Contrechamps, 2007), $593-691$.
} 
content, composed during what can be considered his second creative period (1960-1975). ${ }^{21}$

Für Paul Dessau was composed at a time when Nono's hope of a new world came from the conjunction of the Third World liberation movements and struggles of intellectuals, students, and workers in developed countries. It reveals a "collective climate, a resolute stand in favor of two fundamental human values, freedom and justice."22 However, given the drift of some of these revolutionary projects-from Cuba to China, including Russia-it is important to place Für Paul Dessau in its creative context in order to grasp its complexity and its originality. Therefore, I pay particular attention to the historical contextualization of Nono's political positions and the recorded historical material used in this work, in order to put into perspective his strong belief in the socialist utopia and the strategic function that music politicization had for him. I argue that Für Paul Dessau responded in an original way to the concrete issue of the politicization of music during the Cold War. It connected causes, identified common adversaries, and indicated objectives to be achieved.

\section{Ideology, Hegemony, and the Ethic Behind Nono's Musical Activism}

Nono used Gramsci's notions of organic intellectual, ideology, and hegemony as axes to build and develop his own political and ethical thought. As he stated in 1969, all analyses of his work should take into consideration the ideology behind his activity as a composer:

It is natural that if one does not study and analyze my compositional practice, including its relationship between technique and ideology, but remains conditioned by traditional and nowadays conservative beliefs concerning either technique or the ideological moment that becomes music, one falsifies and equivocates my active position as a musician who is totally engaged in the current political struggle. ${ }^{23}$

Nono's understanding of ideology drew on Gramsci's broad definition of the concept, as "a conception of the world that is implicitly manifest in art, in law, in economic activity and in all manifestations of individual and collective life." 24 For Nono, ideology was a guide for conscious artistic action which should find its source in the common reality of the masses or the working class. In this sense, a composer's choices are never neutral and he or she is responsible for their consequences. There is an ethic that makes it impossible to separate music composition and political reflection. Indeed, Nono talked about the notion of commitment through music in 1966:

When we talk about "commitment" in music today, it is often at the theoretical or technical level, but rarely at the ideological level. Contrary to what many believe, these two forms of commitment are not incompatible. Starting from the most everyday reality, the most current one, relying on the great impulses of rebellion and hope that shake our world, one can, out of all immature realism, realise an imaginative work that satisfies as much the progressive support

\footnotetext{
${ }^{21}$ Paulo de Assis, "Revisiting Luigi Nono's Suffered, Serene Waves," in Artistic Experimentation in Music: An Anthology, ed. Darla Crispin and Bob Gilmore (Leuven: Leuven University Press, 2014), 203.

${ }^{22}$ Erika Schaller, "Für Paul Dessau," in Luigi Nono: Complete Works for Solo Tape, 2 CDs and booklet (Milan: Stradivarius Ricordi Oggi, 2006), 66.

23 "È naturale che se non si studia e analizza la mia pratica compositiva anche nel rapporto tecnico-ideologico, ma si resta condizionati da concezioni tradizionali e oggi restaurative sia della tecnica che del momento ideologico che deviene musica, si falsa e si equivoca la mia attiva posizione di musicista impregnato totalmente nella lotta politica attuale," Luigi Nono, "Il potere musicale (1969)," in Luigi Nono: Scritti e colloqui, ed. Angela Ida De Benedictis and Veniero Rizzardi, vol. I (Milan and Lucca: Ricordi and LIM, 2001), 270.

${ }^{24}$ Antonio Gramsci, Selections from the Prison Notebooks of Antonio Gramsci, ed. and trans. Quintin Hoare and Geoffrey N. Smith (New York: International Publishers, 1971), 328.
} 
of contemporary thought as the great masses. The relationships between the creator and the masses (of the working class in particular) must no longer be those of professor to pupil, of initiator to neophyte. They must first find themselves at the origin of the work. ${ }^{25}$

This text highlights a particular tension in the relationship between the composer and the working class, when the former claims to talk in the name of subaltern people or assumes to represent the working class. In Gramscian terms, organic intellectuals are connected with any social class but are defined by the role and function they accomplish in the social structure. ${ }^{26}$ Geoffrey Nowell Smith asserts that for Gramsci "the organic intellectuals are distinguished less by their profession, which may be any job characteristic of their class, than by their function in directing the ideas and aspirations of the class to which they organically belong." ${ }^{27}$ The central point is the issue of belonging to the social group, since for Gramsci it should be possible "to measure the 'organic quality' [organicità] of the various intellectual strata and their degree of connection with a fundamental social group." ${ }^{28}$ As Robert Adlington points out, Nono followed the interpretation encouraged by the postwar PCI since for him "the 'organic intellectual' allied to the working class was indistinguishable from the politically engaged 'traditional intellectual'." 29 Therefore, Nono "placed the emphasis upon collaboration" 30 instead of focusing on belonging to the working class as the central requirement of organicity.

Concerning the international dimension of class struggle, Nono associated Gramsci's concepts with ideas developed by Frantz Fanon and Ernesto "Che" Guevara in order to think about how Marxist theory, revolutionary strategy, and music composition could be adapted and applied to different historical and cultural contexts. These ideas were an integral part of his compositional practice and his pedagogical activity, as he characteristically notes with regard to his composition course in Uruguay in December 1971:

My composition seminar took place in light of the cultural and political directions of Antonio Gramsci, Frantz Fanon, Ernesto "Che" Guevara, and of the resolution of the Cuban National Congress on Education and Culture of April 1971. We discussed the need to overcome and break both the myth of colonising Eurocentrism and the schematic application of European socialism, which almost never corresponds to the socio-economic cultural reality of Latin America. All technical analyses followed within that context. ${ }^{31}$

\footnotetext{
25 “Lorsqu'on parle d'« engagement», en musique, aujourd'hui, c'est souvent sur le plan théorique ou technique, mais rarement sur le plan idéologique. Or, contrairement à ce que croient beaucoup, ces deux formes d'engagement ne sont pas inconciliables. En partant de la réalité la plus quotidienne, la plus actuelle, en s'appuyant sur les grands élans de révolte et d'espoir qui secouent notre monde, on peut, hors de tout réalisme infantile, faire œuvre d'imagination qui satisfasse autant l'aide marchante de la pensée contemporaine que les grandes masses. Mais les relations du créateur et des foules (de la classe ouvrière en particulier) ne doivent plus être celles de professeur à élèves, d'initiateur à néophytes. Il faut qu'ils se retrouvent d'abord à l'origine de l'œuvre," Le Nouvel Observateur, October 5, 1966, published as Luigi Nono, "Un discours sonore (1966)," in Luigi Nono: Écrits, ed. and trans. Laurent Feneyrou (Genève: Éditions Contrechamps, 2007), $233-34$.

${ }^{26}$ Gramsci contrasted the category of organic intellectuals with that of "traditional intellectuals," connected with old or disappearing social classes and defined by the role and function they had within a historical process (such as the ecclesiastics in their relationship with the landed aristocracy), see Gramsci, Selections from the Prison Notebooks of Antonio Gramsci, 7.

${ }^{27}$ Geoffrey N. Smith, "Introduction to The Intellectuals," in Selections from the Prison Notebooks of Antonio Gramsci, by Antonio Gramsci, ed. Quintin Hoare and Geoffrey N. Smith (New York: International Publishers, 1971), 3.

${ }^{28}$ Gramsci, Selections from the Prison Notebooks of Antonio Gramsci, 12.

${ }^{29}$ Adlington, "Whose Voices?," 191.

${ }^{30}$ Adlington, 191.

31 "Il mio seminario di composizione fu impostato alla luce delle indicazioni culturali politiche di Antonio Gramsci, di Frantz Fanon, di Ernesto 'Che' Guevara et della risoluzione del congresso di educazione cubano dell'aprile del '71. In esso si discusse molto sulla necessità di superare e rompere sia il mito dell'eurocentrismo colonizzante, che l'applicazione schematica della pratica socialista europea, quasi sempre non rispondente alla diversa realtà socioeconomica culturale latinoamericana. E ogni analisi tecnica si svolgeva in tale contesto," Luigi Nono, "Corso latino-americano di musica
} 
Essential in understanding the ethic behind Nono's musical activism is the fact that he considered it a way to resist oppression and injustice, a vital tool for the establishment of socialist hegemony. He claimed that "making music" was something that committed him "in a way that is no different from participating in a demonstration or in a clash with the police, or as could be the case tomorrow, in the armed struggle." 32 This relationship between hegemony and violence is directly related to his reading of Gramsci. As Dylan Riley asserts, "one of the central themes of the Prison Notebooks is the connection between physical violence or force-as exercised either by states or revolutionary movements-and consent." ${ }^{23}$ For Gramsci, any transition to socialism will have to address the armed force, since the revolutionary moments, when "spontaneous consent has failed," 34 are central to creating hegemony.

\section{The Politics of New Technology in Music}

Nono believed that the use of new technology, and the work within the electronic studio, was indispensable for the dissemination of the necessary ideas for cultural and ideological hegemony of the revolutionary forces. The composer should make tangible the ideas, information, and material from political struggles in order to contribute to raising consciousness. To achieve this, the composer should work "with all the resources made available to him by the new audio and visual languages." 35 . Additionally, Nono saw in the electronic studio "a kind of common ground-a shared field-with workers whose existences were fundamentally shaped by confrontation with machines." ${ }^{36}$

From 1960 until the mid-1970s, Nono's use of the Studio di Fonologia of the RAI in Milan was part of the aesthetic and political project of committing both his work, and the means used to produce it, to the advancement of class struggle and social justice. In 1969 he states:

We have to understand and appropriate any element and any technological advance that is actually innovative, that we differentiate and empower by our theoretical and practical conception of the present struggle. That we associate with our capacity for invention and creation for the hegemony, according to Gramsci's term, of the revolutionary forces, in their destructive, constructive, and intellectual practices. An example: the development and application of electronic technology in contemporary music, the electronic studio. It is an advance and an unprecedented expressive possibility for musical creation. ${ }^{37}$

In his text "Music and Power" (Il potere musicale, published in September 1969), Nono insisted on his artistic commitment. His aesthetic position, he wrote, consisted of conceiving "culture as a moment of

contemporanea (1972)," in Luigi Nono: Scritti e colloqui, ed. Angela Ida De Benedictis and Veniero Rizzardi, vol. I (Milan and Lucca: Ricordi and LIM, 2001), 304.

32 "È questo che intendo per far musica: qualche cosa che mi impegna in modo non diverso dalla partecipazione a une dimostrazione o a uno scontro con la polizia, o come potrebbe essere, domani, la lotta armata," Nono, "Il potere musicale (1969)," 268.

${ }^{33}$ Riley, "Hegemony, Democracy, and Passive Revolution in Gramsci’s Prison Notebooks."

${ }^{34}$ Gramsci, Selections from the Prison Notebooks of Antonio Gramsci, 12.

35 “Avec toutes les ressources que mettent à sa disposition les nouveaux langages sonores et visuels," Nono, "Un discours sonore (1966)," 234.

${ }^{36}$ Adlington, "Whose Voices?," 196-97.

37 "Il nous faut comprendre et nous approprier tout élément et toute conquête technique effectivement novatrice, que nous différencions et que nous responsabilisons par notre conception théorique et pratique de la lutte actuelle, et que nous associons alors à notre capacité d'invention et de création pour l'hégémonie, selon le terme de Gramsci, des forces révolutionnaires, dans leur pratiques destructrices, constructives et intellectuelles. Un exemple : le développement et l'application de la technique électronique dans la musique contemporaine, le studio électronique. C'est une conquête et une possibilité expressive inédite pour la création musicale," Luigi Nono, "Entretien avec Luigi Nono," in Luigi Nono: Écrits, ed. and trans. Laurent Feneyrou (Genève: Éditions Contrechamps, 2007), 297. 
awareness, of struggle, of provocation, of discussion, of participation." ${ }^{38}$ This required the critical use of the legacies of the past but also the refusal of any Eurocentric conception, and of any aristocratic vision of culture and artistic languages. Nono's position was related to Gramsci's notion of “culture," and the ethical and social dimensions of knowledge dissemination in order to put forward socialist hegemony:

creating a new culture does not only mean one's own individual "original" discoveries. It also, and most particularly, means the diffusion in a critical form of truths already discovered, their "socialization" as it were, and even making them the basis of vital action, an element of coordination and intellectual and moral order. ${ }^{39}$

Nono opposed his conception of musical activism to the compositional practices of other composers, such as Karlheinz Stockhausen. Nono's critical comments about the West German composer explicitly shed light on his ethical and aesthetic conception of the use of advanced musical technology in relation to political struggles of the time. Nono asserts that Stockhausen considered "technology as a value, a theory of painless technological-aesthetic evolution, a natural connection with the locations of the most advanced technical production, namely the USA and the West, an aristocratic contempt for all other cultures, and let's not even talk about the so-called Third World." ${ }^{40}$

Nono described Stockhausen's position as imperialist, four years before Cornelius Cardew's book Stockhausen Serves Imperialism appeared. He considered that it exalted techno-scientific evolution as the only moment of truth without any critical awareness of the price of exploitation and economic plunder which made this technical development possible. ${ }^{41}$ Nono's criticism was particularly focused on Stockhausen's Hymnen, and its second version Hymnen (Dritte Region) for electronics and a large orchestra, which was commissioned by Leonard Bernstein and the New York Philharmonic Orchestra at the beginning of 1969. Nono's critical comments referred to the way in which Stockhausen made use of a large number of national and political anthems as material for this work. In a revealing interview he gave to the Venezuelan review Rocinante in January 1969, he asserted that

A composer from West Germany, Stockhausen, who campaigns for the use of electronics in composition up to the point of argument and violent personal conflicts, felt the need to use for one of his compositions, Hymnen, acoustic materials historically and geographically situated: national anthems which he treats with "objectivity" and with a certain "feeling of superiority" (the Spanish anthem of the fascist Franco with that of the People's Republic of Albania, or the Italian Communist song Bandiera Rossa with a Nazi song....). ${ }^{42}$

Nono was anxious to reconcile the creative activity of the composer with an ethic and an ideological responsibility specific to the role of the intellectual. He continued his criticism, questioning:

\footnotetext{
38 "Cultura come momento di presa di coscienza, di lotta, di provocazione, di discussione, di partecipazione," Nono, "Il potere musicale (1969),” 268.

${ }^{39}$ Gramsci, Selections from the Prison Notebooks of Antonio Gramsci, 325.

${ }^{40}$ Nono, "Il potere musicale (1969)," 266.

${ }^{41}$ When Nono made this assertion in 1969, Stockhausen had composed at the Studio for Electronic Music of West German Radio in Cologne (Westdeutscher Rundfunk - WDR) several works for electronics with or without instruments, in particular Gesang der Fünglinge (1956), Kontakte (1960), Mixtur (1964), Mikrophonie I (1964), Mikrophonie II (1965), Telemusik (1966) and Hymnen (1966-1967).

42 “Un compositeur de l'Allemagne de l'Ouest, Stockhausen, qui milite pour l'électronique, jusqu'à la polémique et à des conflits personnels violents, a ressenti le besoin d'utiliser pour l'une de ses compositions, Hymnen, des matériaux acoustiques localisées historiquement et géographiquement, des hymnes nationaux qu'il traite avec "objectivité” et avec un certain "sentiment de supériorité" (l'hymne espagnol du fasciste Franco avec celui de la République populaire d'Albanie ou le chant communiste italien Bandiera rossa avec un chant nazi...)," Nono, "Entretien avec Luigi Nono," 298. For an analytical description of the first version of Hymnen, see Jonathan Harvey, “Stockhausen's 'Hymnen," The Musical Times 116, no. 1590 (1975): 705-7, https://doi.org/10.2307/960033.
} 
What sense, then, can there be in speaking about new acoustic space, new environments, a new psychology of listening, of new techniques, of höherer Mensch [higher man] unless they are related to new human social structures no longer based on exploitation or neo-capitalist or neo-colonial domination, in a word, socialist structures, or at least tending toward them? (in which socialism is to be created truly on the ground, and not by mechanically reproducing historically limited models, when what is needed is analytical-critical knowledge). ${ }^{43}$

Seeing composers as organic intellectuals, Nono granted them the hegemonic function of struggling against the conception of the world of the ruling class (bourgeoisie) by musical creation and by promoting a revolutionary and socialist imaginary. This action had to take into account the social, economic, and cultural conditions of their creative activity and its consequences.

The Studio di Fonologia of the RAI in Milan provided Nono with the possibility of realizing a number of unprecedented sonic processes particularly relevant for his political concerns, such as the appropriation of previously recorded sounds and their incorporation into new acoustic spaces, as well as the transformation of sound morphology. Nono used these processes in Für Paul Dessau in order to include in the work some of the most significant social revolutions and emancipation struggles of the twentieth century: the Russian and the Cuban revolutions, the antifascist resistance against Nazism and Fascism, the Vietnam War, and the post-colonial struggles of the Third World during the 1960s and 1970s.

\section{Für Paul Dessau: Political Voices from Liberation Struggles of the Twentieth Century}

For Marxist intellectuals like Nono, the Third World struggles for justice and emancipation seemed to announce a political upheaval on a large scale. He conceived these struggles as a necessary step for the construction of a socialist society, assuming that "there is no difference between the class struggle and that of the people for their liberation." ${ }^{44}$ As he stated in an interview in 1969, "the workers impose a class struggle for socialist power in the factory. The guerrillas impose a head-on class conflict." ${ }^{45}$ In the context of the Cold War and its peripheral conflicts, certain political leaders of the Third World, such as Fidel Castro and Ernesto "Che" Guevara, represented "both the revolutionary struggle against the United States, radical social change and, [for the later], a questioning of the Soviet norm."

In Für Paul Dessau, Nono uses recorded speeches of the historical leaders Vladimir Lenin (18701924), Ernst Thälmann (1886-1944), Patrice Lumumba (1925-1961), Che Guevara (1928-1967), and Fidel Castro (1926-2016). ${ }^{47}$ He mixed the voices by stratification in order to highlight both the semantic

\footnotetext{
43 “Che senso ha, allora, parlare di nuovo spazio acustico, di nuovi ambienti, di nuova psicologia dell'ascolto, di nuove tecniche, di höherer Mensch [uomo superiore] se non sono raportati a nuove strutture sociali umane non basate più sullo sfruttamento sulla dominazione neocapitalista o neocoloniale, in una parola strutture socialiste, o almeno tendenti a esse? (in cui il socialismo sia da creare veramente in loco, e non da riportare meccanicamente a modelli storicamente limitati verso cui pure è necessario una conoscenza analitico-critica)," Nono, "Il potere musicale (1969)," 267.

44 "Il n’y a pas de différence entre la lutte de classes et celle des peuples pour leur libération,” Nono, "Un discours sonore (1966),, 233.

45 "Les ouvriers imposent, dans l'usine de classe, une lutte pour le pouvoir socialiste. Les guérilleros imposent un conflit de classe, frontal," Nono, "Entretien avec Luigi Nono," 302.

${ }^{46}$ Robert Frank, "Imaginaires politiques et figures symboliques internationales : Castro, Hô, Mao et le 'Che," in Les années 68: Le temps de la contestation, ed. Geneviève Dreyfus-Armand et al. (Bruxelles: Editions Complexe, 2000), 35.

${ }^{47}$ Given between 1919 and 1963 in Russian, German, French, and Spanish, the recorded speeches were available to Nono on vinyl records. The use of these recorded voices in Für Paul Dessau linked it with at least three other works by Nono composed during the same period in which he used quotations from texts by Castro, Guevara, and Lumumba: A floresta é jovem e cheja de vida (1966, texts by Fidel Castro, Frantz Fanon, Herman Kahn, and Patrice Lumumba), Y entonces comprendió (1970, texts by Ernesto "Che" Guevara, and Carlos Franqui), Al gran sole carico d'amore (1972-1974, texts by Bertolt Brecht, Tania Bunke,
} 
range of certain words or phrases, and the rhythm and articulation of each language. Nono explained the purpose of his use of historical recording:

I took as theme for this composition our common international struggle. The musical structure is shaped by words from Lenin, extracts from "What is Soviet Power?" and "An Appeal to the Red Army," words from Thälmann, an illegal recording of Lumumba in his cell before his assassination, words from Ernesto Che Guevara about three years of war in Vietnam, and Fidel Castro's "Second Declaration of Havana." This structure is thus constructed to liberate the forces of art and combat, through the synthesis of these words of our time, which bring our struggle and art closer to reality and give them a new dimension. ${ }^{48}$

The use of these archives is highly political not only in terms of the narratives introduced to the audience, but also in terms of the new collective discourse that they produce. ${ }^{49}$ Since archives "are the loci of power of the present to control what the future will know of the past, ${ }^{, 50}$ Nono's use of archives is significant for his purpose of making his listeners aware of the struggles of the past in order to better understand the struggles of the present. He creates "continuity where discontinuity prevailed." 51

In the manner of a cantus firmus, the two speeches of Lenin ${ }^{52}$ - the most sampled throughout the work, with that of Guevara on the Vietnam War-have a structuring function in the work's general polyphony. Recorded in 1919 during the civil war which followed the October Revolution, the aims of the speeches were to motivate the Red Army troops and to explain the revolutionary purpose of the new power given to the soviets. For Lenin, this power

gives those who were formerly oppressed the chance to straighten their backs and to an everincreasing degree to take the whole government of the country, the whole administration of the economy, the whole management of production, into their own hands. Soviet power is the road to socialism that was discovered by the masses of the working people, and that is why it is the true road, that is why it is invincible. ${ }^{53}$

\footnotetext{
Fidel Castro, Ernesto "Che” Guevara, Georgi Dimitrov, Maxim Gorky, Antonio Gramsci, Lenin, Karl Marx, Louise Michel, Cesare Pavese, Arthur Rimbaud, Celia Sánchez, and Haydée Santamaría).

48 “J'ai pris pour thème de cette composition notre lutte commune internationale. Des mots de Lénine, extraits de Qu'est-ce que le pouvoir des Soviets? et de l'Adresse à l'armée rouge, des mots de Thälmann, un enregistrement illégal de Lumumba dans sa cellule, avant son assassinat, des mots d'Ernesto Che Guevara sur trois années de guerre au Viêt-Nam et de la Deuxième Déclaration de La Havane de Fidel Castro déterminent ma structure musicale. Cette structure est ainsi construite pour libérer les forces de l'art et du combat, à travers la synthèse de ces mots de notre temps, lesquels rapprochent de notre réalité le combat et l'art, et leur confèrent une nouvelle dimension," Luigi Nono, "Für Paul Dessau (1974)," in Luigi Nono: Écrits, ed. and trans. Laurent Feneyrou (Genève: Éditions Contrechamps, 2007), 661.

${ }^{49}$ The use of these speeches also highlighted a connection between Nono and Paul Dessau, a testimony of the importance of their friendship and shared political affinities-Dessau composed his Requiem für Lumumba (for soprano, baritone, speaker, choir, and orchestra) in 1963 and his Lenin (for choir and orchestra) in 1969. As Nono stated in an interview of 1973: "the friendship that binds me to him is very important to me because, aside from the admiration I have for his profoundly humanitarian and politically committed artistic contributions, he is also very close to me from a political point of view," ["L'amicizia che mi lega a lui è per me molto importante poiché, a parte l'ammirazione che porto alle sue opere artistiche profondamente umanitarie e politicamente impegnate, mi è anche da un punto di vista politico molto vicino"] Luigi Nono, "Intervista di Jean Villain," in Luigi Nono: Scritti e colloqui, ed. Angela Ida De Benedictis and Veniero Rizzardi, vol. II (Milan and Lucca: Ricordi and LIM, 2001), 141. Quoted in Schaller, "Für Paul Dessau," 66.

${ }^{50}$ Joan M. Schwartz and Terry Cook, "Archives, Records, and Power: The Making of Modern Memory," Archival Science 2, no. 1-2 (March 2002): 13, https://doi.org/10.1007/BF02435628.

${ }^{51}$ Gianmario Borio, "Luigi Nono: Notes on the Relationship Between Music and Technology," in Luigi Nono: Complete Works for Solo Tape, 2 CDs and booklet (Milan: Stradivarius Ricordi Oggi, 2006), 39.

52 "What is Soviet Power?," given at the end of March 1919 and first published in Pravda on January 21, 1928; see Vladimir I. Lenin, "What Is Soviet Power?," in Collected Works, 4th English ed., vol. 29 (Moscow: Progress Publishers, 1972), 248-49. "An Appeal to the Red Army," given on March 29, 1919, see Vladimir I. Lenin, "An Appeal to the Red Army," in Collected Works, 4th English ed., vol. 29 (Moscow: Progress Publishers, 1972), 244-45.

${ }^{53}$ Lenin, "What Is Soviet Power?," 249. I quote only parts of excerpts used by Nono in Für Paul Dessau.
} 
The end of his appeal to the Red Army exalts the victory of socialism proclaimed by Lenin. At the same time, it underlines the international dimension of the struggle of the Russian people: "Comrades, Red Army men! Be staunch, firm and united. March boldly forward against the enemy. Victory will be ours. The power of the landowners and the capitalists, broken in Russia, will be defeated throughout the world." ${ }^{54}$

Lenin's speeches overlay the speech of Che Guevara, who praises the armed struggle of the Vietnamese people against the imperialist aggression of the United States, symbolically linking the October Revolution to the Vietnam War and the Cuban Revolution. Guevara draws a tri-continental geography of Third World resistance: "America, Asia, and Africa, the three oppressed continents were showing signs that they would not tolerate for much longer the presence of the colonial powers." ${ }^{55}$ Nono exposed this genealogy of struggles in 1966 in a speech against the Vietnam War:

The victory of peace for Vietnam and its right [to decide on its own socialist destiny] must be a new victory for the whole worker and anti-imperialist movement, on the path opened by the October Revolution, the Long March, and the Sierra Maestra [and from the growth and achievement of our resistance, for a new world $]{ }^{56}$

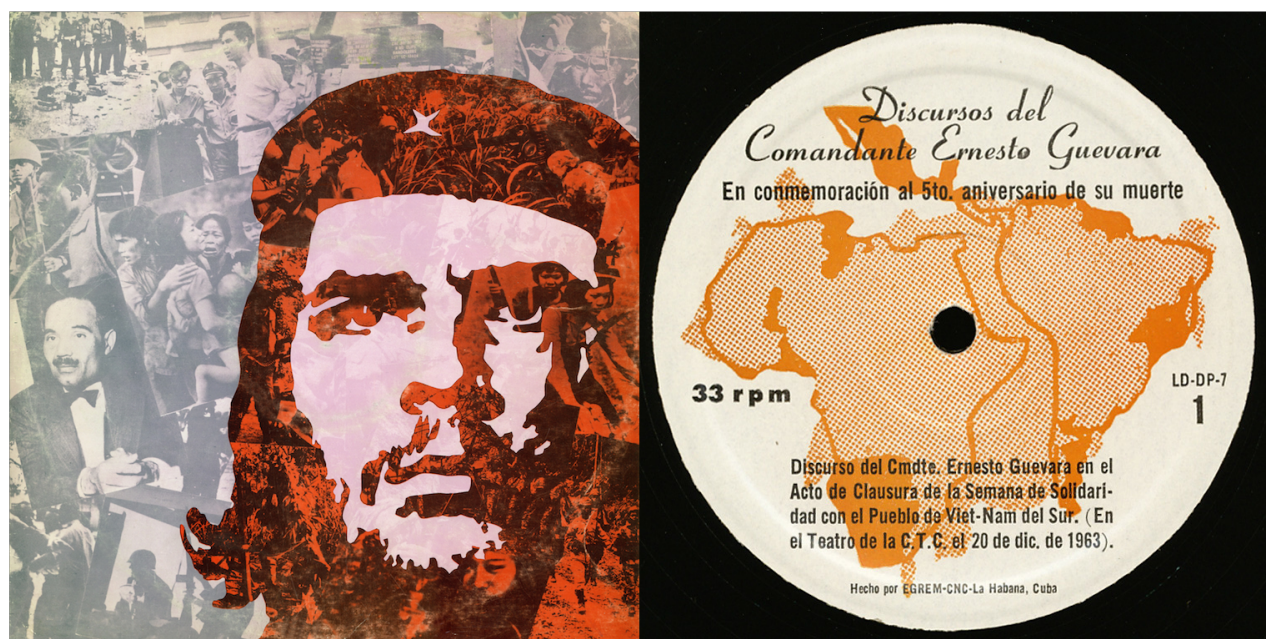

Image 1: Cover and label of the vinyl record of Ernesto "Che" Guevara's speech (given in Havana, December 20, 1963).

Following this international dimension of liberation struggles, Nono included in Für Paul Dessau a speech of Patrice Lumumba, emblematic figure of the struggle for independence of the Belgian Congo and Prime Minister of the new Republic of Congo from June to September 1960. Nono used excerpts of what is considered the last speech of this leader of African decolonization before his execution in January

\footnotetext{
${ }^{54}$ Lenin, “An Appeal to the Red Army,” 245.

55 “América, Asia y África, los tres continentes oprimidos estaban dando señales de que no admitirían por mucho tiempo más la presencia de los poderes coloniales," Ernesto "Che" Guevara, Solidaridad Con Vietnam Del Sur-Discurso Del Comandante Ernesto Guevara En El Acto de Clausura de La Semana de Solidaridad Con El Pueblo de Viet-Nam Del Sur (La Habana: EGREMCNC LD-DP-7, 1963).

56 "La conquista della pace per il Vietnam e il suo diritto [a decidere del proprio destino socialista] devono essere una nuova conquista di e per tutto il movimento operario e antimperialista, sulla strada aperta dall'ottobre rosso, dalla lunga marcia, e dalla Sierra Maestra [e dalla ripresa e dal compimento della nostra resistenza, per un mondo nuovo]," Luigi Nono, "Intervento contro la guerra nel Vietnam (1966)," in Luigi Nono: Scritti e colloqui, ed. Angela Ida De Benedictis and Veniero Rizzardi, vol. I (Milan and Lucca: Ricordi and LIM, 2001), 220. The excerpts in brackets were added by hand to the original draft, by somebody other than Nono.
} 
1961. Lumumba characteristically warns against the various forms of neo-colonialism put in place by the former occupying powers: "we have just fallen into a neo-colonialism, which is as dangerous as the colonialism we just buried on June 30."

Nono also chose excerpts from Fidel Castro's speech in Havana in February 1962, known as the "Segunda Declaración de La Habana." ${ }^{58}$ Castro develops in his speech, with a rhetoric characteristic of the Cold War, the promises of freedom formulated by the Cuban revolution and the Third World liberation struggles. For Nono, the Cuban revolution was proof of the possibility to resist US imperialism. Fidel Castro was the symbol of both the Latin American anti-imperialist struggles against the United States and of the possibility to develop a Latin American model of socialism. In his speech, Castro affirms that "now history will have to take the poor of America into account, the exploited and spurned of Latin America, who have decided to begin writing history for themselves for all time." ${ }^{\text {" I }}$ It develops Guevera's criticism of United States imperialism and aggression, contrasting the United States political stance with the virtues claimed for Cuba in the aftermath of the revolution:

Cuba for the murdered teachers; the United States for the assassins.

Cuba for the truth; the United States for lies.

Cuba for liberation; the United States for oppression.

Cuba for the bright future of humanity; the United States for the past without hope.

Cuba for peace among peoples; the United States for aggression and war.

Cuba for socialism; the United States for capitalism. ${ }^{60}$

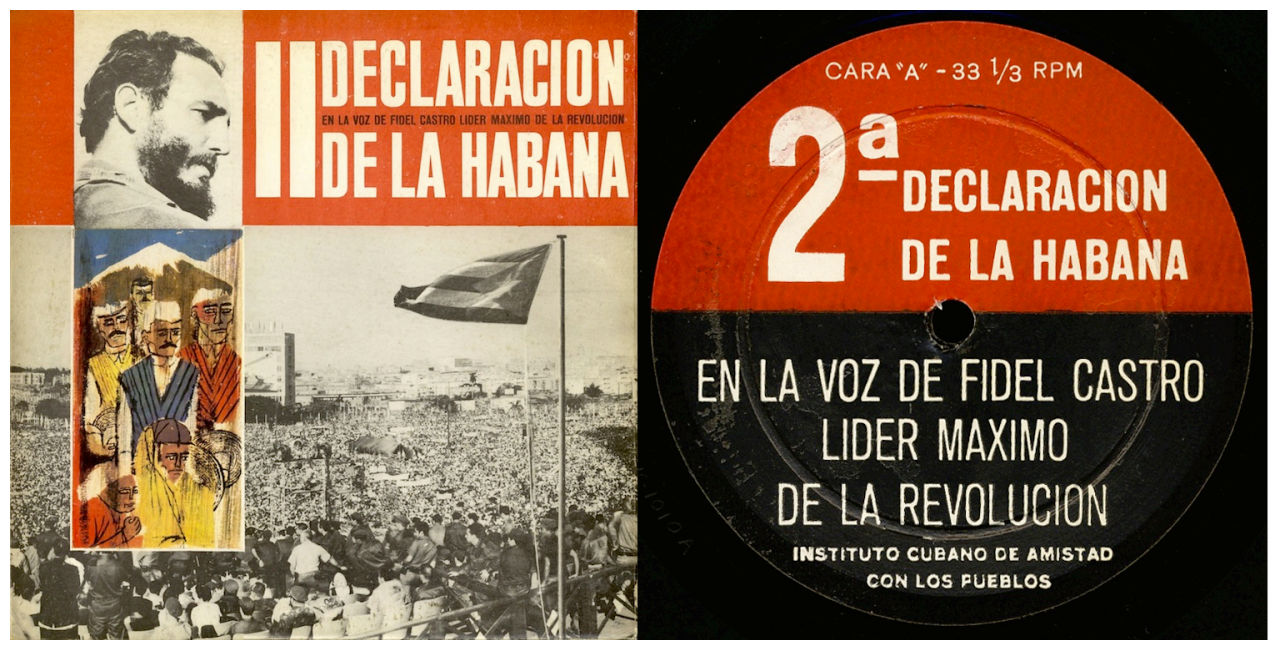

Image 2: Cover and label of the vinyl record of Fidel Castro's speech (given in Havana, February 4, 1962).

The choice to use the speeches of Castro, Guevara, and Lumumba in Für Paul Dessau followed the logic of decentralization and internationalization of the struggles of emancipation and social justice. These

\footnotetext{
57 "Puisqu'on vient de tomber dans un néo-colonialisme, qui est aussi dangereux que le colonialisme que nous venons d'enterrer le 30 juin dernier," Patrice Lumumba, Ultimo Discorso Di Patrice Lumumba (Italia Canta, n.d.).

${ }^{58}$ The speech can be viewed on YouTube: https://youtu.be/GeUcZjAKC s.

59 “Se tendrá que contar con los pobres de América, con los explotados y vilipendiados de América latina que han decido empezar a escribir ellos mismos, para siempre, su historia," Fidel Castro, Segunda declaración de La Habana (La Habana: Instituto cubano de amistad con los pueblos, 1962), speech given in Havana, at the Plaza de la Revolución, February 4, 1962.

60 "Cuba, por los alfabetizadores asesinados; Estados Unidos, por los asesinos / Cuba, por la verdad; Estados Unidos, por la mentira / Cuba, por la liberación; Estados Unidos, por la opresión / Cuba, por el porvenir luminoso de la humanidad; Estados Unidos, por el pasado sin esperanza / Cuba por la paz entre los pueblos; Estados Unidos por la agresión y la guerra / Cuba, por el socialismo, Estados Unidos, por el capitalismo," Castro.
} 
political figures were engaged in an ideological battle against the bipolar vision of the world and wanted to give the peripheral nations a historical role to play. This role was not only political but also ideological and cultural, showing a different path to countries that refused to submit to the geopolitical logic of the two blocs. As Robert Frank points out, "the new multipolarity is therefore not only a geopolitical affair of international power relations, as in the late 1950s. From the mid-1960s onwards, it is at the heart of an ideological, political, and cultural interpretative framework."

Finally, the speech of Ernst Thälmann, an international symbol of German anti-fascist resistance and a national hero in East Germany (RDA), calls to people to "fulfill the main prerequisite tasks for the victory of the proletarian revolution." Intended as a homage for Paul Dessau, Nono greeted the German composer through the words of Thälmann, who transmits to his audience his "fraternal and revolutionary greetings." 62

It is significant to note that both Thälmann and Lumumba can be considered as victims of oppressive and despotic regimes. Thälmann was one of the leaders of the German Communist Party (KPD) and member of the Reichstag from 1924 to 1933 until he was arrested in Berlin by the Nazi regime. He was imprisoned in Bautzen state prison and transferred to Buchenwald concentration camp, where he was assassinated on August 18, 1944. Lumumba was executed by a firing squad at 35 years old in a Katanga prison in January 1961. This is a crime in which the Belgian government and the United States were complicit. On July 17, 1960, the ambassador of the United States in Brussels, Richard Burden, asked the Belgian government to destroy Lumumba's government: "A principal objective of our political and diplomatic action must therefore be to destroy [the] Lumumba government as now constituted, but at the same time we must find or develop another horse to back which would be acceptable in [the] rest of Africa and defensible against soviet political attack." ${ }^{63}$ As I analyze in the next section, the themes of the antifascist resistance and the victims of imperialist violence were particularly important for Nono.

\section{From Antifascism to the Revolutionary Left: Compositional Synthesis in Für Paul Dessau}

Nono used excerpts from recordings of three of his own works in order to structure and frame dramatically the political speeches: Il canto sospeso (1955-1956, for soprano, contralto, tenor, and orchestra), Non consumiamo Marx (1969, for magnetic tape), ${ }^{64}$ and Como una ola de fuerza y luz (1971-1972, for soprano, piano, orchestra, and magnetic tape). This material creates a self-referential system that greatly expanded the symbolic scope of Für Paul Dessau.

First of all, Il canto sospeso, based on letters written by captured members of the European resistance before execution by the Nazis, creates a link with the antifascist struggle during and after the Second World War. This work was of great significance to Nono. In recollecting its conception and creation, he

\footnotetext{
${ }^{61}$ Frank, "Imaginaires politiques et figures symboliques internationales : Castro, Hô, Mao et le 'Che," 36.

62 "Die Voraussetzungen für die großen Aufgaben des Sieges der proletarischen Revolution zu erfüllen. Und in diesem Sinne überbringe ich dem Kongreß die brüderlichsten und die revolutionärsten Grüße," Ernst Thälmann, Ansprache in Moskau (Moscow, 1928), https://archive.org/details/SelectedWeimarEraPoliticalSpeechesPart2/1928-02-15-ErnstThaelmannkpdAnspracheInMoskau2m06s.mp3.

${ }^{63}$ Madeleine G. Kalb, The Congo Cables: The Cold War in Africa-from Eisenhower to Kennedy (New York: Macmillan, 1982$), 27$. For an overview of the responsibilities of the Belgian and the United States governments, see the report of the 2001 Belgian Commission investigating Lumumba's assassination (http://www.lachambre.be/kvvcr/showpage.cfm?section $=\% 7 \mathrm{Ccomm} \% 7 \mathrm{Clmb} \&$ language $=$ fr\&story $=1 \mathrm{mb} . \mathrm{xml} \& \mathrm{rightmenu})$. ${ }^{64}$ Non consumiamo Marx is the second part of Musica-Manifesto $n$. 1 . The first part, Un volto, e del mare, used a text by Cesare Pavese (Mattino) and is written for two female voices and magnetic tape.
} 
makes a link with the work of Gramsci:

These were the years of the great rediscovery of the writings of Antonio Gramsci, the brutal Scelbian ${ }^{65}$ repression, the anti-fascist front, and the continuing and discussed presence of the Resistenza. [...] Years of great unrest, polemical, political, and cultural struggles; that we felt perhaps more and in which we participated in Italy. Which required rigorous preparation, open and innovative study, analysis of the real situation, in contrast to the ways of thinking and dogmatisms in use, choices and often violent conflicts. ${ }^{66}$

Luigi Nono's early political works, such as Il canto sospeso, were a denunciation of the crimes committed by Nazism and Fascism. They then became in the sixties, according to Laurent Feneyrou, "a condemnation of the type of society that leads to the Hitlerisms of yesterday and today." ${ }^{27}$ Following this idea, Non consumiamo Marx was conceived as a manifesto against the cultural, social, and economic wrongs of capitalism, as it was composed from recordings of the slogans used during the Paris events of May 1968 and sounds from the demonstrations against the Venice Biennale in June 1968. Nono dedicated this work "to Carlos Franqui, a Cuban revolutionary poet," and explicitly wrote about the three "documents" he used:

1) Poetical: Mattino by [Cesare] Pavese-woman, sea, nature, and love.

2) From the street: Venice, June 1968. The boycott and struggle of students, workers and intellectuals against the Biennale. Commercial cultural institution, acquired for the interests of monopolies (Montedison and Ciga) and governmental power. Recordings by the Venetian comrade P. Penso.

3) Mural-political: twenty slogans from the walls of buildings in Paris (May 1968)—struggle against the capitalist state and personal (political) power (De Gaulle).

-Human experiences of the class struggle of our time, offering new perspectives, a new meaning and a new praxis to the amoroso-pavesiano movement (Embrasse ton amour sans laisser ton fusil)

-Voice-based electronic composition technique (recorded, developed, composed, and live) on original electronic material. ${ }^{68}$

Finally, Como una ola de fuerza y luz was dedicated to the memory of Luciano Cruz, a young leader of

\footnotetext{
${ }^{65}$ From the Christian-Democratic politician Mario Scelba (1901-1991), Minister of the Interior from 1947 to 1953 , who ruthlessly suppressed the protests and strikes of left-wing workers, and wrote the so-called 'Scelba law', formally banning neo-fascist organizations but also restraining the activities of the Italian Communist Party.

66 “C'étaient les années de la grande redécouverte des écrits d'Antonio Gramsci, de la brutale répression scelbienne, du front antifasciste et de la présence continue et discutée de la Resistenza. [...] Années de grandes agitations, luttes polémiques, politiques et culturelles. Que nous ressentions peut-être plus et auxquelles nous participions, en Italie. Et qui exigeaient une rigueur de préparation, d'étude ouverte et innovante, et d'analyse sur le réel, contre les modèles et les dogmatismes en usage, de choix et de conflits souvent violents," Luigi Nono, "Il canto sospeso (1955-1956)," in Luigi Nono: Écrits, ed. and trans. Laurent Feneyrou (Genève: Éditions Contrechamps, 2007), 604. Following the premier in Cologne on October 24, 1954, Nono wrote to Paul Dessau: "Never before did I experience such tension in the audience with my work! Tension as total silenzio, no noise throughout the performance, nothing," quoted in Nielinger-Vakil, Luigi Nono, 22.

${ }^{67}$ Laurent Feneyrou, Il Canto Sospeso de Luigi Nono (Paris: Michel de Maule, 2002), 14.

68 “1) Poetico - Pavese Mattino - Donna mare natura amore. 2) Di Strada - Venezia, giugno 1968. Boicottaggio e lotta di studenti - operai - intellettuali contro la biennale. Ente culturale mercificante a sostegno di interessi economici monopolisti (Montedison-Ciga) e del potere governativo. Registrazioni effettuate dal compagno veneziano P. Penso. 3) Murale-politico 20 scritte sui muri di Parigi - maggio 1968 - lotta contro lo stato capitalista e personalistico (De Gaulle). - Situazioni umane della lotta di classe nel nostro tempo, in cui il momento amoroso-pavesiano riceve nuova prospettiva e significato e prassi (Embrasse ton amour sans laisser ton fusil). - Tecnica compositiva elettronica basata su voci - registrate elaborate composte - e dal vivo - su materiale elettronico originale," Luigi Nono, "Musica-Manifesto n. 1: Un volto, e del mare - Non consumiamo Marx," in Luigi Nono: Scritti e colloqui, ed. Angela Ida De Benedictis and Veniero Rizzardi, vol. I (Milan and Lucca: Ricordi and LIM, 2001), 468.
} 
the Chilean Movimiento de Izquierda Revolucionaria (MIR, Revolutionary Left Movement) who Nono met in Santiago during the summer of 1971, before he was assassinated in August of that year. Nono wrote about Cruz and the genesis of his work:

His intelligence and extraordinary Marxist capacity to fight for Chilean freedom gave me an immediate and admirative friendship with him. In September 1971, I suddenly received news of his strange accidental death at only 27 years old. These are the reasons behind this music. [...] His presence-absence determined the choice of the sound structure, its purpose. I expanded the first draft of this project with the introduction of the voice (soprano) on a few verses chosen from a poem dedicated to Luciano Cruz by the Argentine poet Julio Huasi, a friend of Luciano who I also met in Santiago. ${ }^{69}$

Nono articulates these works with the political speeches both temporally and spatially. On the spatial level, Nono organized Für Paul Dessau stereophonically, ${ }^{70}$ as he placed his own works in the center, the voices of Lenin and Guevara on the left channel, and those of Thälmann, Lumumba and Castro on the right channel (see table below). One interpretation of this spatial distribution is that Nono desired to "situate" geographically, to "territorialize" these works and speeches, while making them dialogue through a polyphonic articulation. This analogy between the acoustic space of the work and geographical space served to connect to the present the emancipation struggles to which past sounds and speeches refer.

\begin{tabular}{|l|r|r|}
\hline Left channel & Centre & Right channel \\
\hline Russian, Spanish & & German, French, Spanish \\
\hline $\begin{array}{l}\text { Vladimir I. Lenin: } \\
\text { 'What is Soviet Power?' (1919) } \\
\text { 'An Appeal to the Red Army' (1919) }\end{array}$ & Il canto sospeso (1955-1956) & $\begin{array}{r}\text { Ernst Thälmann: } \\
\text { Speech given in Moscow (1928) } \\
\text { Patrice Lumumba: } \\
\begin{array}{l}\text { Ernesto 'Che' Guevara: } \\
\text { 'Solidarity with South Vietnam' (1963) }\end{array} \\
\end{array} \quad$ Como una ola de fuerza y luz (1971-1972) \\
'Last speech of Patrice Lumumba' (1960) \\
Fidel Castro: \\
'Second Declaration of Havana' (1962)
\end{tabular}

Table 1: Spatial distribution of musical works and speeches used in Für Paul Dessau

The main countries where the revolutionary struggles are evoked in the speeches are on four continents: Asia (Russia and Vietnam), Africa (Congo), Europe (Germany), and Latin America (Cuba, Chile). Given that Nono's works refer to historical events in Europe (Il canto sospeso, Non consumiamo Marx) and Latin America (Como una ola de fuerza y luz), the choice of placing them in the center of the sound space gives them a unifying function in relation to the struggles articulated in the speeches. This spatial organization links the "peripheral" struggles to the legacy and experience of Nono himself, and simultaneously identifies Latin America as the place for renewing hope for the international socialist movement in the context of the Cold War. ${ }^{71}$

\footnotetext{
69 "La sua forte intelligenza e straordinaria capacità marxiste di combattente per la libertà cilena, mi suscitò ammirata immediata amicizia per lui. Nel settembre del 1971 mi giunse improvvisa la notizia della sua morte accidentale strana, a soli 27 anni. È la motivazione di questa mia musica. [...] La sua presenza-assenza mi determinò nella scelta definitiva della struttura sonora, del suo perché. Ampliai il primo progetto con l'inserimento della voce (soprano) su alcuni versi scelti da un poema del poeta argentino Julio Huasi, amico di Luciano e da me conosciuto pure a Santiago, poema per Luiciano Cruz," Luigi Nono, "Como una ola de fuerza y luz," in Luigi Nono: Scritti e colloqui, ed. Angela Ida De Benedictis and Veniero Rizzardi, vol. I (Milan and Lucca: Ricordi and LIM, 2001), 479-80.

${ }^{70}$ As Erika Schaller asserts, Luigi Nono created the stereophonic version of the tape (used at the premiere in Berlin) from four channels, see Schaller, "Für Paul Dessau," 64.

${ }^{71}$ Nono was particularly attached to the socialist project of Salvador Allende. He saw him as a leader of the international
} 


\section{Making Visible the Struggles of the Past: The Sounds of the Resistenza}

The musical works and speeches used in Für Paul Dessau refer to historical, political, and cultural events that were of great importance to Nono. He articulated and developed them on the temporal level through two main types of sections, which are alternated throughout. First, the discourse sections (DS) based mainly on the articulation of political speeches supported by excerpts of Nono's works. Secondly, the interludes (I) based exclusively on Nono's works put together by juxtaposition or by progressive stratification. Finally, an introduction and a coda, based also exclusively on Nono's works, which open and close Für Paul Dessau (see table and example below).

\begin{tabular}{|c|c|c|c|c|c|c|c|c|c|c|c|c|c|c|c|c|c|c|}
\hline & \multirow{2}{*}{$\begin{array}{l}0^{\prime} 00^{\prime \prime} \\
\text { Intro }\end{array}$} & \multirow{2}{*}{$\begin{array}{l}0^{\prime} 17^{\prime \prime} \\
\text { DS }\end{array}$} & \multirow{2}{*}{ 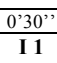 } & \multirow{2}{*}{$\begin{array}{l}0^{\prime} 33^{\prime \prime} \\
\text { DS 2 }\end{array}$} & \multirow{2}{*}{$\begin{array}{c}1^{\prime} 00^{\prime \prime} \\
\mathbf{I} 2\end{array}$} & \multirow{2}{*}{$\begin{array}{l}1^{\prime \prime 11} 1^{\prime \prime} \\
\text { DS }\end{array}$} & \multirow{2}{*}{$\frac{1^{\prime} 20^{\prime \prime}}{} \mathbf{I 3}$} & \multirow{2}{*}{$\begin{array}{l}1^{\prime 2} 26^{\prime \prime} \\
\text { DS }\end{array}$} & \multirow{2}{*}{$\frac{1{ }^{\prime} 54^{\prime \prime}}{\mathbf{I} 4}$} & \multirow{2}{*}{$\begin{array}{l}2^{\prime} 07^{\prime \prime} \\
\text { DS }\end{array}$} & \multirow{2}{*}{\begin{tabular}{|c|}
$2^{\prime} 43^{\prime \prime}$ \\
$\mathbf{5} 5$
\end{tabular}} & \multirow{2}{*}{$\begin{array}{l}2^{\prime} 56^{\prime \prime} \\
\text { DS } 6\end{array}$} & \multirow{2}{*}{$\frac{4^{\prime} 15^{\prime \prime}}{\text { I } 6}$} & \multirow{2}{*}{$\begin{array}{l}4^{\prime} 33^{\prime \prime} \\
\text { DS 7 }\end{array}$} & \multirow{2}{*}{$\begin{array}{c}5^{\prime} 24^{\prime \prime} \\
\text { I } 7\end{array}$} & \multirow{2}{*}{$\begin{array}{l}5^{\prime} 30^{\prime \prime} \\
\text { DS 8 }\end{array}$} & \multirow{2}{*}{$\begin{array}{l}\text { 6.33" } \\
\text { Coda }\end{array}$} \\
\hline & & & & & & & & & & & & & & & & & & \\
\hline \multirow{3}{*}{$\begin{array}{l}\frac{\tilde{x}}{\dot{b}} \\
\dot{0}\end{array}$} & Non consumiamo Marx & * & * & & * & $*$ & & * & * & $*$ & & $*$ & * & $*$ & & & & \\
\hline & Il canto sospeso & * & * & * & * & * & * & * & * & * & * & * & * & * & $*$ & * & * & * \\
\hline & Como una ola de fuerza y luz & * & & & * & * & & & * & * & & * & * & * & * & & & * \\
\hline \multirow{5}{*}{ 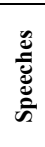 } & Guevara & & * & & * & & & & * & & * & & * & & * & & * & \\
\hline & Lenin & & * & & * & & * & & * & & * & & * & & * & & * & \\
\hline & Castro & & * & & & & & & & & * & & * & & * & & * & \\
\hline & Thälmann & & & & & & & & * & & & & & & & & & \\
\hline & Lumumba & & * & & * & & * & & * & & * & & * & & * & & * & \\
\hline
\end{tabular}

Table 2: Use of political speeches and Nono's works in Für Paul Dessau

The formal function of interludes is to frame the discourse sections in order to better control their emotional dimension. Nono chose the excerpts of his works according to their dramatic strength. They are mostly polyphonic, ranging from a $p p$ when accompanying and supporting speeches in discourse sections to ff during introduction, interludes, and coda. Some works carry the continuity between discourse sections and interludes, such as Il canto sospeso which constitutes the sonic thread that runs throughout the work.

The instrumental and vocal sounds in the discourse sections support the dramatic progression, which is not only semantic as it is also based on timbre, resonance, and polyphonic textures. He transformed the morphology and space of most of the excerpts of his works through the addition of reverb or the use of speed variations, transpositions, and different kinds of filtering. The analysis of specific aspects of the introduction and conclusion of Für Paul Dessau can be helpful for appreciating how Nono developed these processes. The introduction (0'00" - 0'17') is composed by the juxtaposition and progressive stratification of heterogeneous elements from three works: piano sounds transposed and vocals transformed with reverb (Como una ola de fuerza y luz), transposed instrumental excerpts (Il canto sospeso), and rumors and shouts of demonstrations (Non consumiamo Marx). The assembly of these elements creates a sound event with a new dynamic profile.

socialist movement, as he wrote in a telegram to President Allende a few months before the coup d'état of September 11, 1973 that overthrew the Chilean democratic regime. As Erika Schaller points out, Nono initially planned to give a central place to the question of socialism in Chile in Für Paul Dessau, giving it the provisional title Da Lenin ad Allende (un montaggio). See Luigi Nono, "Luigi Nono a Salvador Allende (1973)," in Luigi Nono: carteggi concernenti politica, cultura e Partito comunista italiano, ed. Antonio Trudu (Venezia: L.S. Olschki and Archivio Luigi Nono, 2008), 199; Schaller, "Für Paul Dessau,” 65. 


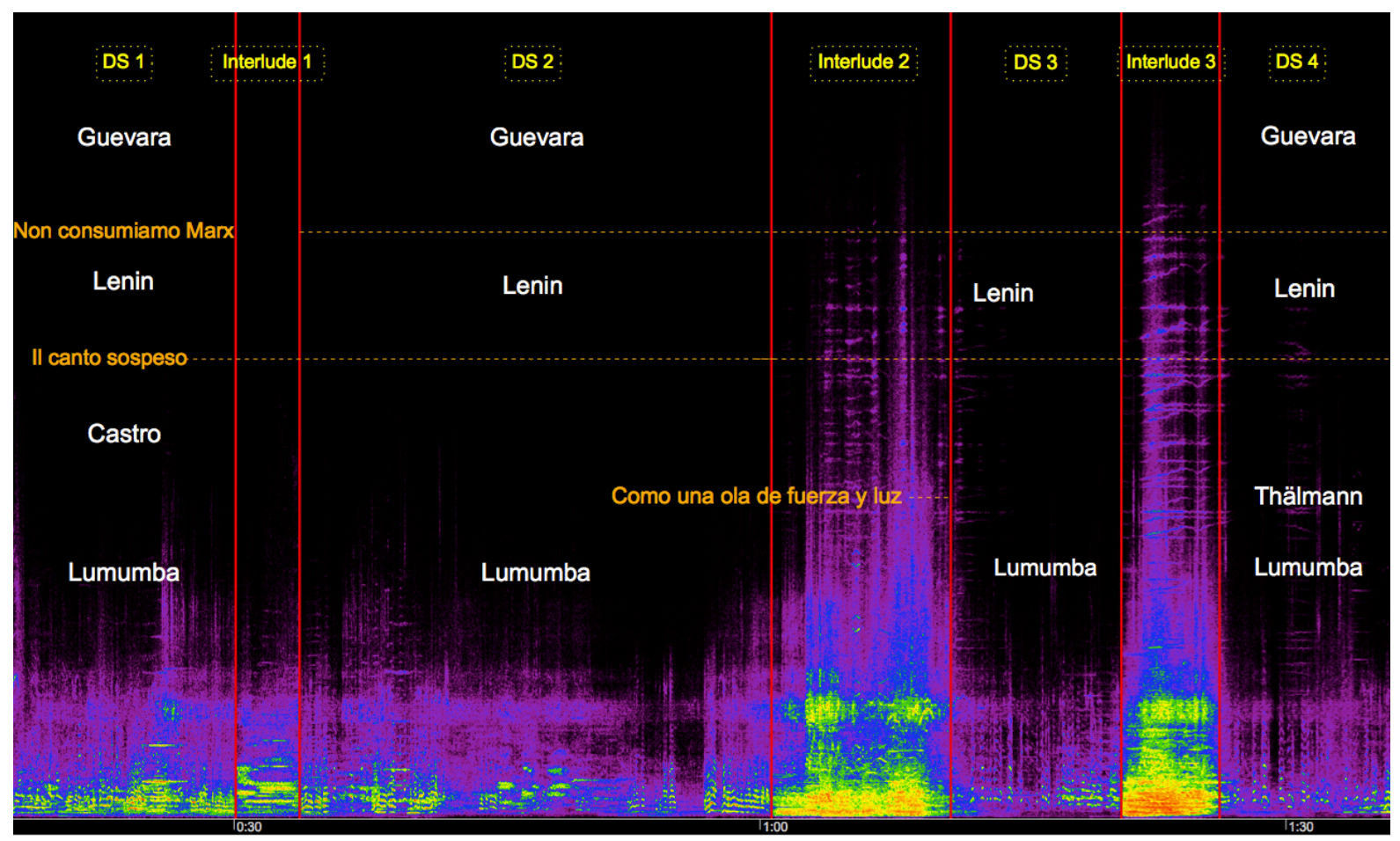

Example 1: Sonogram of the distribution of excerpts of Nono's works and political speeches in the first four discourse sections and three interludes of Für Paul Dessau (0'17'-1'35").

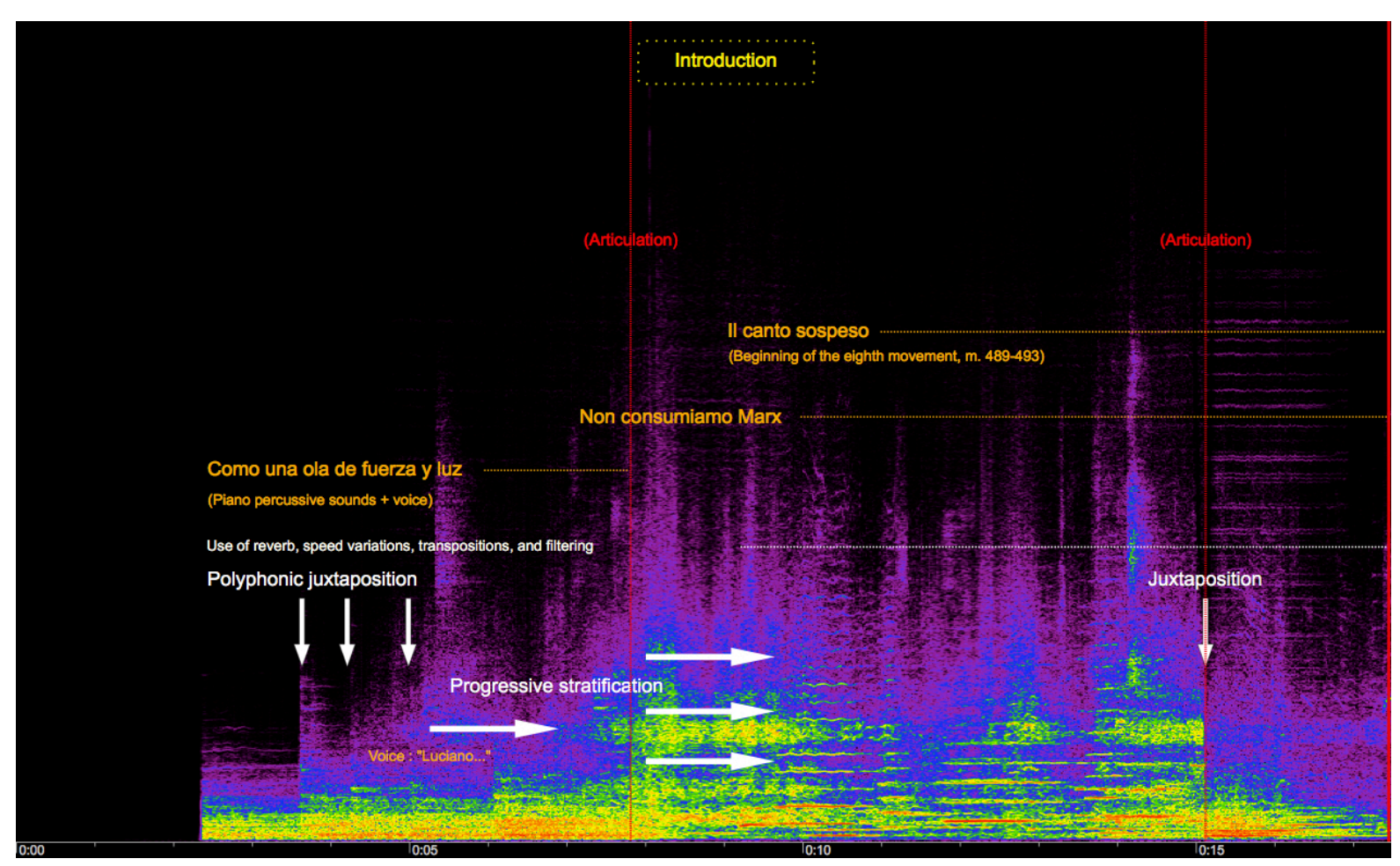

Example 2: Sonogram of the introduction of Für Paul Dessau (0’00” - 0’17’')

Nono concludes the coda (6'33" - 6'57') with the first line of the solo soprano of the seventh movement of Il canto sospeso. It is a quote from the end of the letter by Ljuba Sevcova, a young Ukrainian member of the resistance in the mining town of Krasnodon, sent to her mother. Knowing she would be 
killed by the Nazi occupation forces, she wrote: “... farewell, Mother, your daughter Ljubka is going to the damp earth..."72 (see example below).

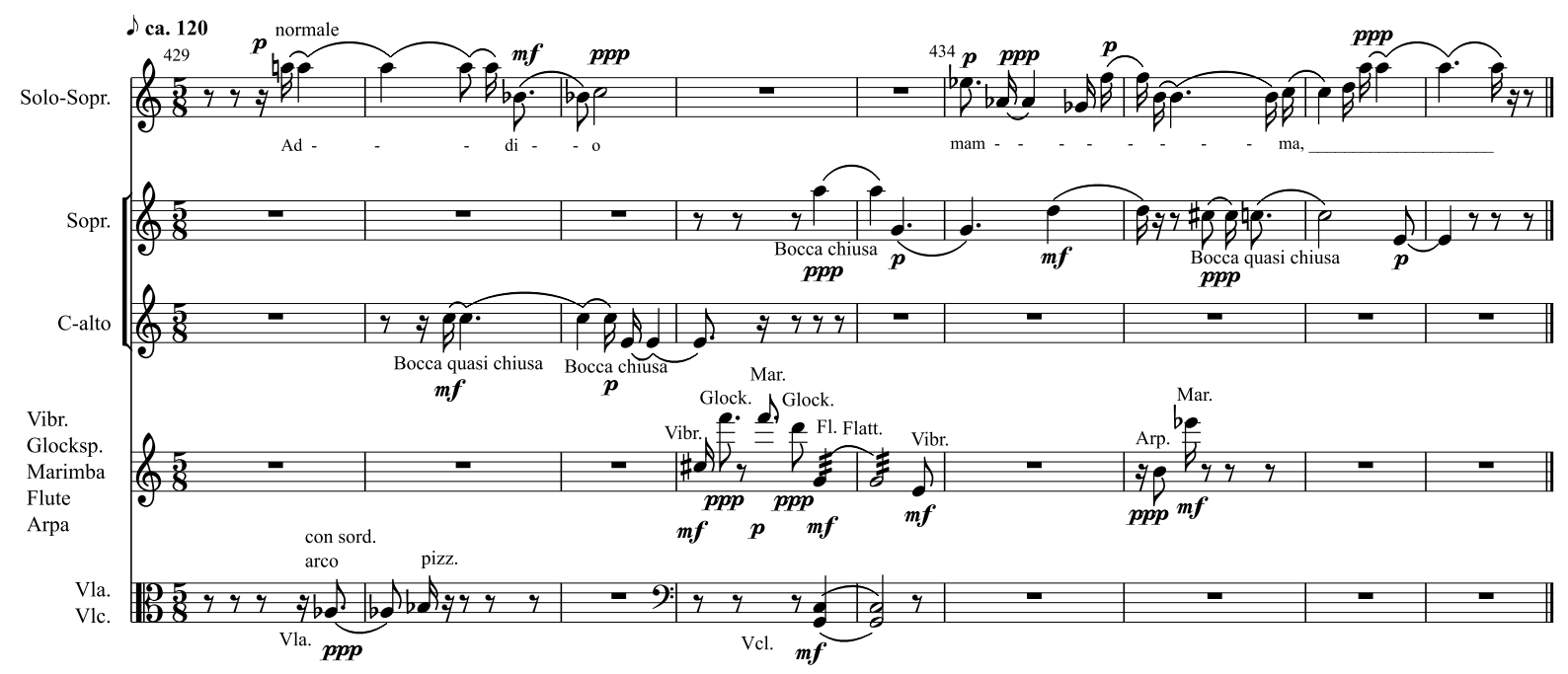

Example 3: Excerpt of the seventh movement of Il canto sospeso (m. 429-437) used in the coda of Für Paul Dessau (6’33"-6'57')

Nono's decision to end Für Paul Dessau with this emotional fragment of Il canto sospeso can be interpreted in terms of his understanding of the Resistenza: "not only the heroic anti-fascist partisan movement, but also the ongoing struggle for a democratic and just, socialist society." 73 The Resistenza was a perpetual struggle that existed both within armed conflicts and far beyond, in everyday choices, efforts, and acts of creation:

The Resistance, as a genuinely revolutionary and fundamental act of our lives, requires, provokes and forms particular choices and an innovative consciousness. And it does so not only, and not once and for all, in the moment of armed struggle, but in its complex continuity. [...] Resistance is not, then, in some limited sense a glorious banner of the past, but rather an unremitting struggle and a new consciousness in continuous development through subjective action, its aim being the objective process that leads to those ideals for which so many fell and continue even now to be murdered..$^{74}$

The musician participates actively in this struggle, extending it into the present through "his studies, his research, his experiments, his inventive imagination." ${ }^{" 75}$ Furthermore, for Nono the full self-realization of the musician is reached at the moment "he manages to bring into a dialectical relationship its two constitutive elements, the ideal on the one hand and the technical-linguistic on the other, with their

\footnotetext{
72 “....addio mamma, tua figlia Ljubka se ne va nell'umida terra...” (quoted in Feneyrou, Il Canto Sospeso de Luigi Nono, 205). Ljuba Sevcova was tortured and killed on 7 February 7, 1943 by an SS-Rottenführer (see Feneyrou, 213-14).

${ }^{73}$ Nielinger-Vakil, Luigi Nono, 6.

74 "La Resistenza, come atto concretamente rivoluzionario e fondamentale della nostra vita, necessita provoca e forma scelte precise e coscienza innovatrice, non esclusivamente, e una volta per sempre, al tempo della lotta armata, ma nella sua complessa continuità. [...] Non limitatamente un glorioso vessillo del passato, quindi, ma lotta incesante e nuova coscienza in continuo sviluppo per l'azione soggetiva e nell'intenzionalità sul processo oggetivo conseguente ai princìpi ideali per cui tanti caddero e vengono tuttora assarrinati," Luigi Nono, “Musica e Resistenza (1963)," in Luigi Nono: Scritti e colloqui, ed. Angela Ida De Benedictis and Veniero Rizzardi, vol. I (Milan and Lucca: Ricordi and LIM, 2001), 144.

75 "I suoi studi, le sue ricerche, i suoi esperimenti, con la sua fantasia inventiva," Nono, 144.
} 
particular requirements and properties." In music, the theme of the Resistenza is "not to be associated only with the use of texts and situations of partisan struggle, in other words, frozen in time." One should instead seek the legacy of the Resistenza "potentially present in those expressions where the truth and the novelty of research, inventiveness and realization broaden and develop that imaginative ability, receptive intelligence and human consciousness which strives for the elimination of the various garrote of neocapitalistic society and for socialist liberation." ${ }^{" 78}$ The political scope of the composer's creative work updates the legacy of the struggles of the past by making it visible in the struggles of the present, which is one of the main concerns of Für Paul Dessau.

\section{Conclusion}

Through the synthesis and spatialization of speeches and composed sounds, Für Paul Dessau gave voice to the Third World in a unified symbolic space, bringing together postcolonial struggles and anchoring them in a socialist tradition. The political dimension of Für Paul Dessau betrays a conscious strategy for socialist hegemony. This consisted of giving voice to specific actors by making them visible in the common space, and of legitimizing ideas and concepts in order to reflect on a common social world. This is in line with Jacques Rancière's concept of the "distribution of the sensible," and the capacity of art practices to contribute "to the constitution of a form of common sense that is 'polemical,' to a new landscape of the visible, the sayable and the doable."

Nono believed that "if a score cannot provoke or incite revolution, it can contribute to it by participating in intellectual and revolutionary hegemony. ${ }^{" 80}$ He developed this idea asserting that "a score can mature and evolve into direct and concrete participation of the struggle, which can be confronted and transposed into the score." ${ }^{81}$ Using the sonic processes made possible by electronics, Für Paul Dessau transposes and symbolically links the voices of an archipelago of political struggles of the twentieth century. It outlines a cartography of historical social revolutions and Third World struggles for emancipation and social justice. As an activist-musician, Nono sought to associate political militancy and symbolic creation in order to fulfill the hegemonic function that he granted to organic intellectuals. Für Paul Dessau underlined both his responsibility for and commitment to the necessary cultural, political, and social transformation of his time.

\footnotetext{
76 "In quanto egli dialettizza le sue due formanti, ideale e tecnico-linguistica, nelle loro particolari esigenze e propretà," Nono, 144.

77 "Non è quindi da collegare unicamente all'uso di testi e di situazioni di lotta partigiana, cioè fermato del tempo," Nono, 145.

78 "Potenzialmente presente in quelle espressioni in cui la verità e la novità di ricerca, di inventiva e di realizzazione amplia e sviluppa la capacità fantastica, l'intelligenza ricettiva e la coscienza dell'uomo teso all'eliminazione delle varie garrote della società neocapitalistica, per la liberazione socialista," Nono, 145.

${ }^{79}$ Jacques Rancière, “The Paradoxes of Political Art," in Dissensus: On Politics and Aesthetics, trans. Steven Corcoran (London: Bloomsbury Academic, 2013), 149. Paulo de Assis also examines Nono's music after 1975 in terms of Rancière's politics of aesthetics, see Assis, "Revisiting Luigi Nono's Suffered, Serene Waves,” 204. For a complementary discussion on Rancière's thought and its application to the relationship between music and politics, see Luis Velasco Pufleau, "Reflections on Music and Propaganda," Contemporary Aesthetics 12 (2014), http://hdl.handle.net/2027/spo.7523862.0012.007.

80 "Si une partition ne peut pas provoquer ou susciter une révolution, elle peut y contribuer, en participant à l'hégémonie intellectuelle et révolutionnaire," Nono, "Entretien avec Luigi Nono," 301.

81 "Une partition peut mûrir et se résoudre dans la participation directe et concrète de la lutte, qui peut être affrontée et transposée dans la partition,” Nono, 301.
} 


\section{Bibliography}

Adlington, Robert. "Whose Voices? The Fate of Luigi Nono's Voci Destroying Muros." Journal of the American Musicological Society 69, no. 1 (2016): 179-236. https://doi.org/10.1525/jams.2016.69.1.179.

Assis, Paulo de. "Revisiting Luigi Nono's Suffered, Serene Waves." In Artistic Experimentation in Music: An Anthology, edited by Darla Crispin and Bob Gilmore, 203-13. Leuven: Leuven University Press, 2014.

Borio, Gianmario. "Luigi Nono: Notes on the Relationship Between Music and Technology." In Luigi Nono: Complete Works for Solo Tape, 36-39. 2 CDs and booklet. Milan: Stradivarius Ricordi Oggi, 2006.

Capuzzo, Paolo, and Sandro Mezzadra. "Provincializing the Italian Reading of Gramsci." In The Postcolonial Gramsci, edited by Neelam Srivastava and Baidik Bhattacharya, 34-54. New York and London: Routledge, 2012.

Castro, Fidel. "Segunda declaración de La Habana." La Habana: Instituto cubano de amistad con los pueblos, 1962.

Eley, Geoff. "Reading Gramsci in English: Observations on the Reception of Antonio Gramsci in the English-Speaking World 1957-82.” In Contemporary Applications, edited by James Martin, 28-60. Vol. 4 of Antonio Gramsci: Critical Assessments of Leading Political Philosophers. London: Routledge, 2002.

Feneyrou, Laurent. Il Canto Sospeso de Luigi Nono. Paris: Michel de Maule, 2002. , ed. Luigi Nono: Écrits. Translated by Laurent Feneyrou. Genève: Éditions Contrechamps, 2007.

Frank, Robert. "Imaginaires politiques et figures symboliques internationales : Castro, Hô, Mao et le 'Che." In Les années 68 : Le temps de la contestation, edited by Geneviève Dreyfus-Armand, Robert Frank, Marie-Françoise Lévy, and Michelle Zancarini-Fournel, 31-47. Bruxelles: Editions Complexe, 2000.

Gramsci, Antonio. Selections from the Prison Notebooks of Antonio Gramsci. Edited and translated by Quintin Hoare and Geoffrey N. Smith. New York: International Publishers, 1971.

Guevara, Ernesto "Che." Solidaridad Con Vietnam Del Sur_Discurso Del Comandante Ernesto Guevara En El Acto de Clausura de La Semana de Solidaridad Con El Pueblo de Viet-Nam Del Sur. La Habana: EGREMCNC LD-DP-7, 1963.

Harvey, Jonathan. “Stockhausen’s 'Hymnen.”' The Musical Times 116, no. 1590 (1975): 705-7. https://doi.org/10.2307/960033.

Kalb, Madeleine G. The Congo Cables: The Cold War in Africa-from Eisenhower to Kennedy. New York: Macmillan, 1982.

Lenin, Vladimir I. “An Appeal to the Red Army.” In Collected Works, 4th English ed., 29:244-45. Moscow: Progress Publishers, 1972.

. "What Is Soviet Power?” In Collected Works, 4th English ed., 29:248-49. Moscow: Progress Publishers, 1972. 
Lumumba, Patrice. Ultimo Discorso Di Patrice Lumumba. Italia Canta, n.d.

Nielinger-Vakil, Carola. Luigi Nono: A Composer in Context. Cambridge: Cambridge University Press, 2015.

Nono, Luigi. "Como una ola de fuerza y luz." In Luigi Nono: Scritti e colloqui, edited by Angela Ida De

Benedictis and Veniero Rizzardi, I:479-81. Milan and Lucca: Ricordi and LIM, 2001.

—. Complete Works for Solo Tape. 2 CDs and booklet. Milan: Stradivarius Ricordi Oggi, 2006.

. "Corso latino-americano di musica contemporanea (1972)." In Luigi Nono: Scritti e colloqui, edited by Angela Ida De Benedictis and Veniero Rizzardi, I:302-6. Milan and Lucca: Ricordi and LIM, 2001.

- "Entretien avec Luigi Nono." In Luigi Nono: Écrits, edited and translated by Laurent Feneyrou, 296-304. Genève: Éditions Contrechamps, 2007.

. "Für Paul Dessau (1974)." In Luigi Nono: Écrits, edited and translated by Laurent Feneyrou, 661.

Genève: Éditions Contrechamps, 2007.

. "Il canto sospeso (1955-1956)." In Luigi Nono: Écrits, edited and translated by Laurent Feneyrou, 601-6. Genève: Éditions Contrechamps, 2007.

. "Il potere musicale (1969)." In Luigi Nono: Scritti e colloqui, edited by Angela Ida De Benedictis and Veniero Rizzardi, I:261-71. Milan and Lucca: Ricordi and LIM, 2001.

- "Intervento contro la guerra nel Vietnam (1966)." In Luigi Nono: Scritti e colloqui, edited by Angela Ida De Benedictis and Veniero Rizzardi, I:216-20. Milan and Lucca: Ricordi and LIM, 2001.

. "Intervista di Hansjörg Pauli." In Luigi Nono: Scritti e colloqui, edited by Angela Ida De Benedictis and Veniero Rizzardi, II:23-33. Milan and Lucca: Ricordi and LIM, 2001.

- "Intervista di Jean Villain." In Luigi Nono: Scritti e colloqui, edited by Angela Ida De Benedictis and Veniero Rizzardi, II:129-43. Milan and Lucca: Ricordi and LIM, 2001.

- "Luigi Nono a 'L’Unità' [Venezia, gennaio 1971].” In Luigi Nono: carteggi concernenti politica, cultura e Partito comunista italiano, edited by Antonio Trudu, 177-80. Venezia: L.S. Olschki and Archivio Luigi Nono, 2008.

—_. "Luigi Nono a Salvador Allende (1973)." In Luigi Nono: carteggi concernenti politica, cultura e Partito comunista italiano, edited by Antonio Trudu, 199. Venezia: L.S. Olschki and Archivio Luigi Nono, 2008.

. "Musica e Resistenza (1963)." In Luigi Nono: Scritti e colloqui, edited by Angela Ida De Benedictis and Veniero Rizzardi, I:144-47. Milan and Lucca: Ricordi and LIM, 2001.

- "Musica-Manifesto n. 1: Un volto, e del mare - Non consumiamo Marx." In Luigi Nono: Scritti e colloqui, edited by Angela Ida De Benedictis and Veniero Rizzardi, I:468-69. Milan and Lucca:

Ricordi and LIM, 2001.

—. "Un discours sonore (1966)." In Luigi Nono: Écrits, edited and translated by Laurent Feneyrou, 233-36. Genève: Éditions Contrechamps, 2007. 
_ . "Una lettera di Luigi Nono: 'Sono un musicista militante' (1971).” In Luigi Nono: Scritti e colloqui, edited by Angela Ida De Benedictis and Veniero Rizzardi, I:288-89. Milan and Lucca: Ricordi and LIM, 2001.

_. "Une lettre de Luigi Nono : 'Je suis un musicien militant.'” In Luigi Nono: Écrits, edited and translated by Laurent Feneyrou, 347-48. Genève: Éditions Contrechamps, 2007.

Rancière, Jacques. "The Paradoxes of Political Art." In Dissensus: On Politics and Aesthetics, translated by Steven Corcoran, 134-51. London: Bloomsbury Academic, 2013.

Riley, Dylan J. "Hegemony, Democracy, and Passive Revolution in Gramsci’s Prison Notebooks." California Italian Studies 2, no. 2 (2011). https://escholarship.org/uc/item/5x48f0mz.

Schaller, Erika. "Für Paul Dessau." In Luigi Nono: Complete Works for Solo Tape, 64-67. 2 CDs and booklet. Milan: Stradivarius Ricordi Oggi, 2006.

Schwartz, Joan M., and Terry Cook. "Archives, Records, and Power: The Making of Modern Memory." Archival Science 2, no. 1-2 (March 2002): 1-19. https://doi.org/10.1007/BF02435628.

Smith, Geoffrey N. "Introduction to The Intellectuals." In Selections from the Prison Notebooks of Antonio Gramsci, by Antonio Gramsci, 3-4. edited by Quintin Hoare and Geoffrey N. Smith. New York: International Publishers, 1971.

Thälmann, Ernst. Ansprache in Moskau. Moscow, 1928. https://archive.org/details/SelectedWeimarEraPoliticalSpeechesPart2/1928-02-15ErnstThaelmannkpd-AnspracheInMoskau2m06s.mp3.

Velasco Pufleau, Luis. "Reflections on Music and Propaganda." Contemporary Aesthetics 12 (2014). http://hdl.handle.net/2027/spo.7523862.0012.007.

Velasco-Pufleau, Luis. "Conflits armés, idéologie et technologie dans Für Paul Dessau de Luigi Nono.” Transposition. Musique et sciences sociales, no. 4 (2014). https://doi.org/10.4000/transposition.1060. 